driven by the profit motive and resistant to even a hint of transparency, have little concern for academic integrity. Nevertheless, this current data collection seems to show that, if they make academic integrity a fundamental building block of their institutional culture, private universities can create a climate to combat the grim perspectives of corruption overshadowing higher education systems in the former Soviet Union.

\section{The Transformations in}

\section{Mexican Higher Education in the I990s}

\section{ROLLIN KENT}

Rollin Kent is professor at the Autonomous University of Puebla, Mexico. E-mail: rkent@puebla.megared.net.mx. This article is an excerpt froma presentation made at the 16th Annual Conference of the Consortium of Higher Education Researchers, Porto, Portugal, September 2003.

rom the perspective of the late i980s, the future of Mexican $\boldsymbol{F}$ higher education seemed somber indeed. No one would have predicted that by 2003 an accreditation system would be in place, that public universities would be doing strategic planning, and that there would be 40 new two-year technical institutes, more than $\mathrm{I} 60$ four-year technical colleges, Io new polytechnic universities, a rapidly growing postgraduate level, and a booming private sector with a growing interest in on-line programs.

It is noteworthy that these changes occurred without a major reform movement in the political sense. There has been public debate, of course, but it certainly lacked the intensity that one would have expected, given the ideological climate of the I980s. With the exception of student opposition at the National University (UNAM) to the attempt at raising fees, it turns out that every other public university in Mexico has raised fees moderately without much ado-a significant ideological shift in itself. The media pounced on the exception and downplayed the larger picture.

These transformations have not been the result of widely debated legislative decisions. They have been undertaken without legal reforms of any significance. The executive branch of government used its considerable authority and, of course, the power of the purse. For financially starved universities, the economic incentives set forth by the federal secretary of education were irresistible.

\section{Funding for Higher Education}

Between I989 and 200I total public expenditures for education as a proportion of GDP increased from 3.7 percent to 5.2 percent. Federal expenditures on higher education as a propor- tion of GDP almost doubled from 0.4 percent to 0.7 percent, going from U.S.\$1.4 billion to U.S.\$3.9 billion in the same period. Although figures for state expenditures are not available on a comparable basis, these figures also increased. Nevertheless, a closer look at the figures would reveal a less significant increase in terms of per student expenditures. Complaints by state university rectors are a constant, especially when they (rightly) point out that the enormous federal institutions with great political clout, like UNAM, get an unfairly large share of public funding. Overall, however, federal and state spending for education, with an emphasis on basic education, has remained a priority throughout the decade.

These figures tell only part of the funding story. Private expenditures in higher education have also grown over the past decade. Data from household income surveys show that the percentage of total family income spent on higher education has doubled since 1992. Figures for corporate donations are not available, but many large private universities depend more and more on this type of funding, as evidenced by the growing number of private foundations. If the data were available, they would certainly reveal a significant increment in private fund-

\section{The percentage of total family income spent on} higher education has doubled since 1992.

ing for higher education overall.

\section{Social Participation and Equity Issues}

The trends in funding mentioned here are manifestations of the growing social demand and willingness to pay for higher education that were the driving forces behind enrollment expansion. National enrollments increased by 70 percent in the I990s. Women and private-sector enrollments took up much of this growth. Also notable is the relative growth outside the capital city: regional expansion of higher education is a very important part of the current changes.

Nonetheless, the participation rate of I9-to-23-year-olds in higher education is still quite low, compared to other Latin American countries that have also reformed their systems, such as Argentina or Chile. While the middle and upper strata are sending their children to higher education, this is not so for lower-income families. In spite of its growth, Mexican higher education remains very inequitable. Household income surveys show that public subsidies favor middle- and upperincome over lower-income families. Expansion does not necessarily lead to social mobility, if poor students lack financial aid or if institutions are not within reach of the rural population. The opportunity costs of higher education for poor rural students in a transition economy such as Mexico's can also be very high: many young people between 15 and 20 years of age from the poorer rural areas in southern Mexico decide to emigrate illegally to the United States rather than continue studies beyond secondary school. The growth of private establishments, which are all based in large cities and charging fees, 
does little to offset social inequality.

Persistent inequity is thus a crucial issue for higher education policy, but it was not recognized as such when the reforms were initiated in the early I990s. At that time quality was the main concern, and that remained the case throughout the decade. However, by the mid-I99os the single-minded emphasis on quality was criticized by examiners of higher education from the Organization for Economic Cooperation and Development, who pointed out severe inequities. Since then and continuing into the Fox administration, there has been a greater emphasis on providing higher education to poor students and young people from rural areas. Issues concerning indigenous groups have climbed onto the agenda.

\section{Persistent inequity is thus a crucial issue for higher education policy, but it was not recog- nized as such when the reforms were initiated in the early 1990s.}

\section{Institutional Diversification}

The public sector has developed a whole range of two-year and four-year technical institutes. All of the establishments are part of the push toward decentralization. They are partly funded by the federal government, but it is up to state governments to carry out the planning, partial funding, and coordination of these institutes - most of them located in small cities and rural areas. The goal of this policy is twofold: to provide opportunities to preparatory school graduates in poor urban and rural settings and to strengthen technical capacity and links with firms at the local level.

A new sector of research and postgraduate institutes has received consistent support, as part of federal policy for research and development. These centers tend to specialize in certain areas of R\&D, such as applied mathematics, optics, metallurgy, biotechnology, and marine sciences. Their mission is to develop strong links with firms and to train new generations of scientists. Perhaps implicit in this decision is the realistic assessment of the weak scientific capacity of state universities. Recent studies have shown a much less agile response by universities to federal incentives for strengthening research capacity than was expected earlier on.

Most notable in this story of institutional diversification, of course, is the expansion of private establishments. Similar trends are evident in other developing countries, such as South Africa, the Philippines, or Brazil. In Mexico, the number of private establishments tripled in II years. Most are small academies with feeble infrastructure and part-time faculty who do not normally hold Ph.D.s.

There are profits to be made in a market under the prevailing conditions. Demand for higher education diplomas is on the rise, and barriers to entry are low. Relatively small investments in facilities and infrastructure are required. Technology costs can be high, but this investment is optional if your installation is surrounded by Internet cafes. Official requirements for quality control have not been stringent in the recent past, although policymakers are currently tightening these controls. There is a relatively qualified workforce seeking jobs in a buyer's market: higher education graduates are having trouble finding work and often accept low wages for part-time employment. Additionally, no legal distinction between for-profit and nonprofit higher education exists, which facilitates the expansion of the for-profit sector.

Notably, academically consolidated universities have doubled in number over the decade. Some of these universities have matured-having started out as small establishments, they grew into more academic institutions or specialized technical colleges as a result of academic entrepreneurship. Others are actually spin-offs from previously well-established academic institutions, taking one of a number of routes. Expansion through franchising is a model followed by the Monterrey Technical Institute, which today has large campuses in more than 20 states throughout Mexico; entrepreneurial growth with support from a religious order means going from single to multicampus establishments; expansion through buyoutsin 2000 , Sylvan Learning Systems in the United States bought into Universidad del Valle de México, which has since set up campuses in several cities. Their publicity offers on-line programs and opportunities for international study. Monterrey Technical Institute has also developed a Virtual University that offers on-line programs to clients throughout Mexico and other Spanish-speaking countries. On-line programs from

\section{Accreditation is being widely promoted by the federal government and by several accrediting organizations.}

other countries, mostly the United States, are also on offer.

Accreditation is being widely promoted by the federal government and by several accrediting organizations. This process is still in its infancy, and while only a small proportion of all institutions or programs are currently accredited, the trend is certainly set to grow in the future. Thus, there is also a new market for accreditation, with opportunities for accreditation mills of various stripes.

\section{A New Policy Agenda}

Mexico has undertaken significant transformations in higher education, not unlike other developing countries. It is noteworthy, however, that these changes did not involve deep political confrontations and widespread social movements, in spite of the fact that the country's political system has undergone notable reforms toward democratization and decentralization. Nonetheless, important issues remain unresolved. The emphasis on quality improvement and institutional diversification has done little to redress social inequality in higher education, which is undoubtedly the foremost challenge today. 